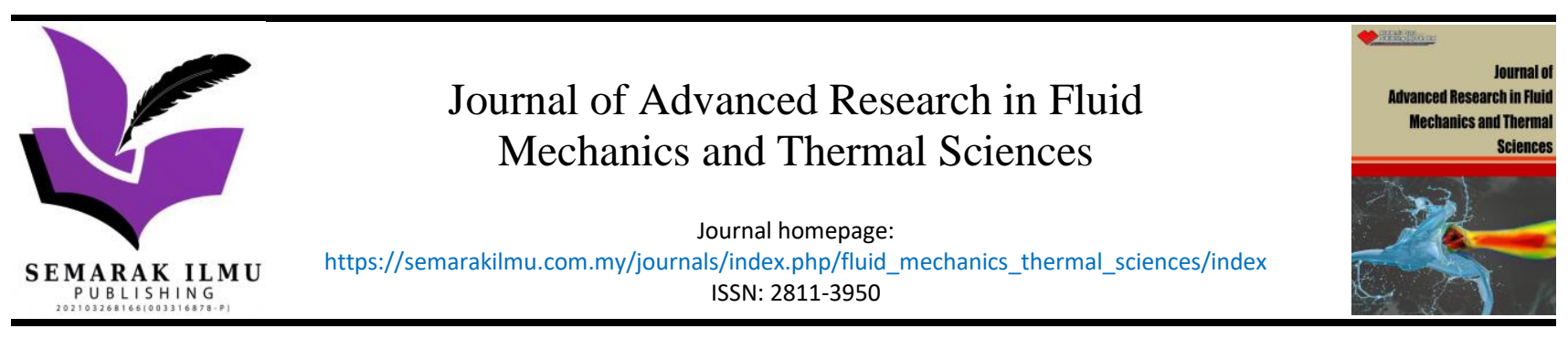

\title{
Performance on Regenerative Braking System on a Through-The-Road Hydraulic Hybrid Vehicle
}

\author{
Tan Pe $\mathrm{Hao}^{1}$, Muhammad Iftishah Ramdan ${ }^{1, *}$, Khairul Anuar Idris ${ }^{1}$, Muhammad Syafiq Abdul \\ Rashid $^{1}$, Muhamad Haziq Haris Patilah ${ }^{1}$, Mohd Azmi Ismail ${ }^{1}$, Inzarul Faisham Abdul Rahim ${ }^{1}$ \\ 1 School of Mechanical Engineering, Engineering Campus, Universiti Sains Malaysia, Pulau Pinang, Malaysia
}

\begin{tabular}{|c|c|}
\hline ARTICLE INFO & ABSTRACT \\
\hline Article history: & Hydraulic Hybrid Vehicle (HHV) has a great potential to be an efficient drive train for \\
\hline Received 27 July 2021 & passenger vehicle, yet most of the HHV drive train studies are focused on heavy-duty \\
\hline Received in revised form 6 December 2021 & vehicles. In order to apply the HHV drive train in passenger vehicles, the performance of \\
\hline Accepted 10 December 2021 & the regenerative braking system of the through-the-road (TTR) parallel architecture HHV \\
\hline Available online 25 January 2022 & $\begin{array}{l}\text { needs to be tested. The performance of the HHV drive train is captured by the overall } \\
\text { efficiency of the hydraulic pump and the mechanical efficiency of the hydraulic motor. } \\
\text { This paper obtains the efficiencies of the hydraulic pump and motor by building a test rig }\end{array}$ \\
\hline Keywords: & to measure their torque using load cells. The highest overall efficiency of the pump is $82 \%$ \\
\hline $\begin{array}{l}\text { Regenerative braking; hydraulic hybrid } \\
\text { vehicle }\end{array}$ & $\begin{array}{l}\text { and the highest mechanical efficiency of the motor is } 74 \% \text {. Both highest efficiencies are } \\
\text { achieved when the regenerative braking system operates at pressure of } 75 \text { bar. }\end{array}$ \\
\hline
\end{tabular}

\section{Introduction}

According to the International Energy Agency (IEA), global average fuel consumption improved by $0.7 \%$ from cars sold in $2017[1,2]$. This is partly due to the use of hybrid electric vehicles (HEV) such as Toyota Prius and Honda Insights [1]. Even though an HEV can reduce fuel consumption and emission $[3,4]$, it is not widely utilized especially in developing countries due to its expensive price $[5,6]$. Another shortcoming of an HEV is its battery performance and life are sensitive to the extreme temperature and charging/discharging rate [5].

A Hybrid Hydraulic Vehicle (HHV) could be the answer for a widely available efficient passenger vehicle. This is because a hydraulic hybrid is more durable, and its performance is not sensitive to the environment temperature or charging/discharging rate [7]. An HHV maintenance should also be reasonable because it is a mechanical system that can be maintained by any mechanics. However, most HHV studies about the HHV involve heavy-duty vehicles such as buses and trucks $[8,9]$. This study investigates the performance of the relatively small HHV to be implemented in passenger vehicles.

\footnotetext{
* Corresponding author.

E-mail address: shahramdan@usm.my
}

https://doi.org/10.37934/arfmts.91.2.6271 
The HHV can exist in three architectures: Parallel, series and power split. Among the three, the parallel architecture is the simplest and least expensive because of its closed resemblance to the conventional vehicle. Under the parallel architecture, there is a configuration called through-theroad (TTR) that allows the use of a front-wheel drive (FWD) conventional vehicle as platform [10]. The TTR allows the retrofitting of the hydraulic regenerative braking system into an existing conventional vehicle, increasing its attainability [10].

The TTR drive train that is used in this study consists of a hydraulic regenerative braking system on a rear axle of a FWD compact passenger car (Figure 1). A hydraulic pump converts the mechanical power to fluid power by generating flow to overcome pressure induced by the load [11]. A hydraulic pump is used to decelerate the vehicle and to charge the accumulator during braking. The pump used in the application is a $25 \mathrm{cc} / \mathrm{rev}$ external gear pump [12]. Gear pumps are relatively cheaper to obtain and easier to repair as compared to other types of pumps as they have fewer moving parts [13]. On the other hand, hydraulic motor is a mechanical actuator that converts fluid energy to rotary mechanical energy that is used to propel the vehicle and discharge the accumulator. [14]. The hydraulic motor used in this study is a $50 \mathrm{cc} / \mathrm{rev}$ geroler hydraulic motor [15].

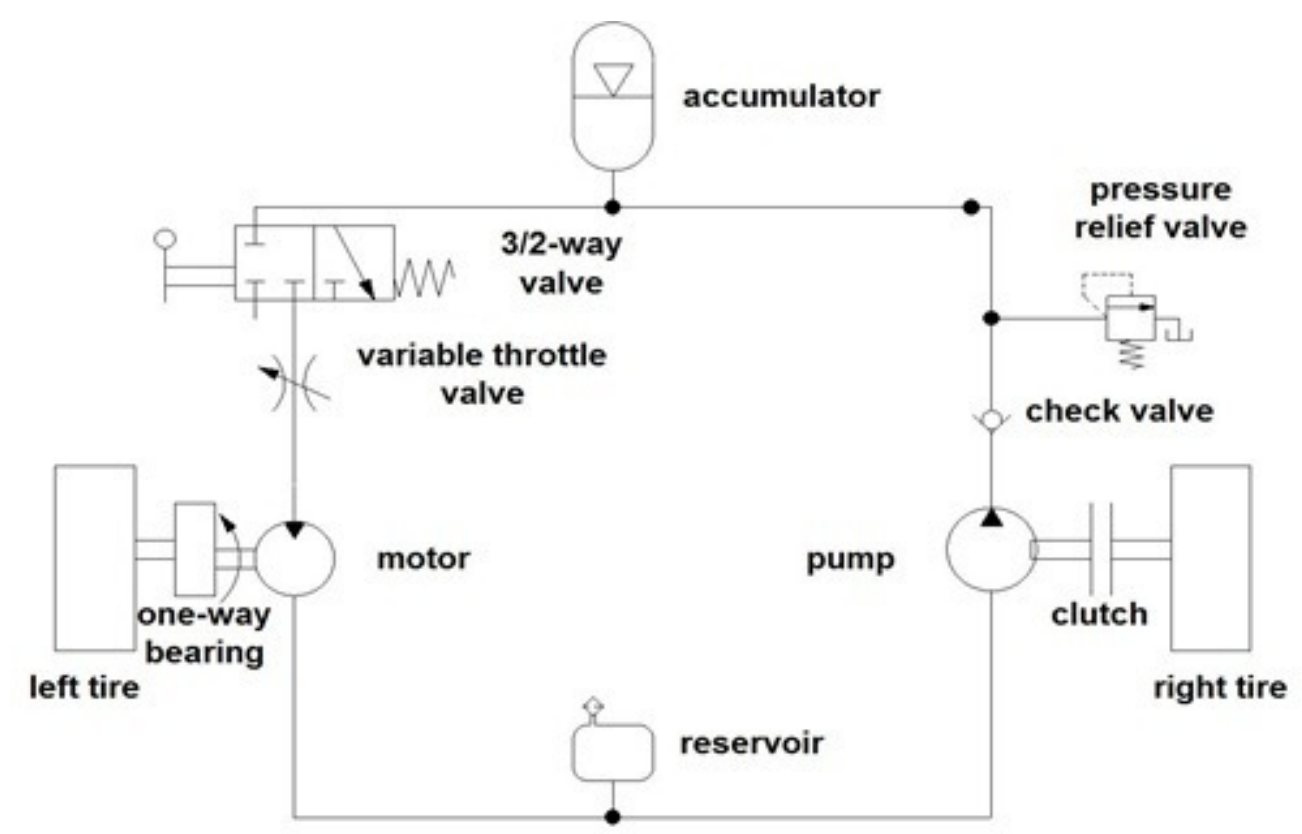

Fig. 1. TTR schematics

This paper investigates experimentally the performance of the regenerative braking system in terms of overall efficiency of the pump, mechanical efficiency of the motor and charging time. An electric motor is used to provide various torque and speed to the right tire (coupled to the hydraulic pump), mimicking the braking process to charge the accumulator at various target pressure (Figure 1). The charged accumulator is used to drive the hydraulic motor at various values of pressure. The efficiencies of the pump and motor are calculated from the recorded torque and speed.

\section{Methodology}

The experimental setup (Figure 2) consists of a hydraulic motor, a hydraulic pump, an electromagnetic clutch, a pressure regulating valve, a one-way check valve, a reservoir, an accumulator, a normally closed (NC) solenoid valve, a variable throttle valve, a 10hp electrical motor, 
an inverter, load cells and also a rear axle from a compact passenger car (Perodua Myvi). The schematic diagram for the setup is as shown in Figure 3.

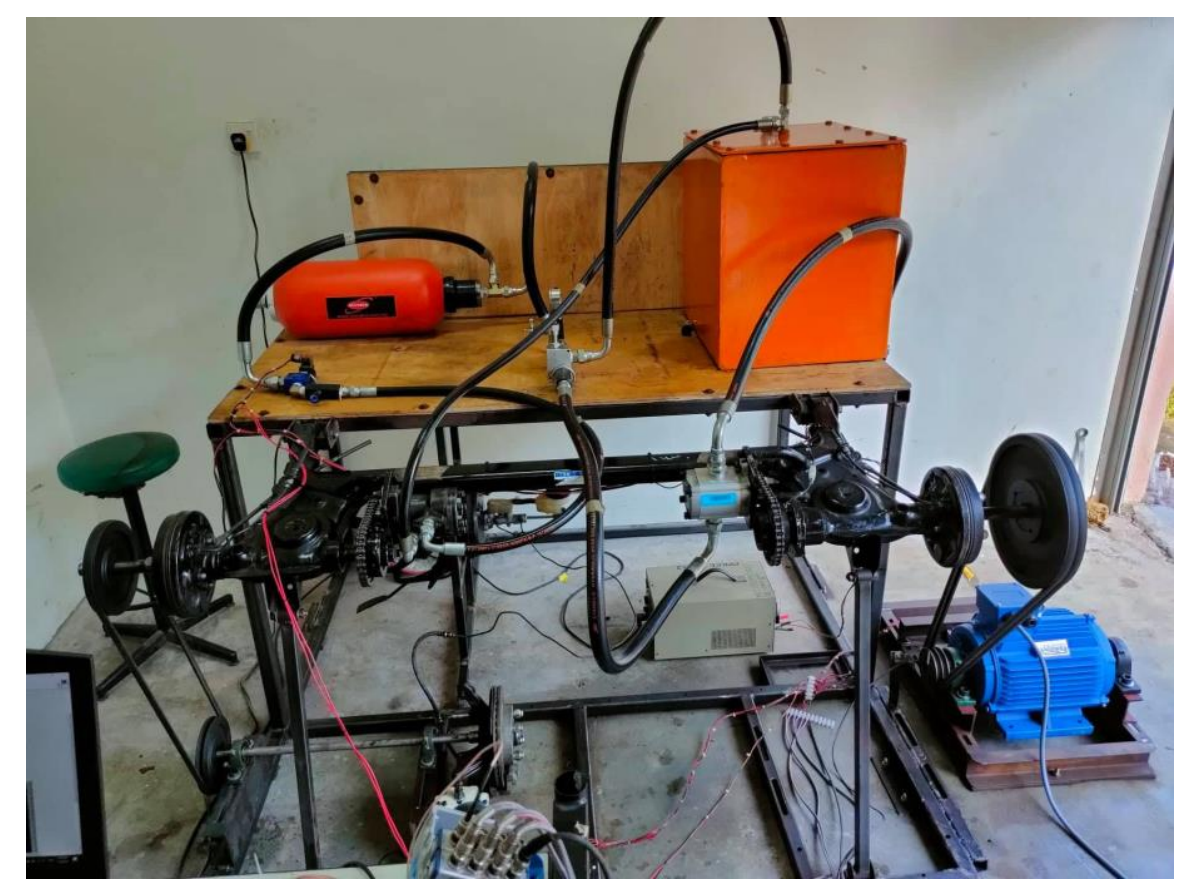

Fig. 2. The experimental setup

The experiment is divided into two parts, charging process and discharging process. Charging process is when the accumulator is charged by the pump and discharging process is when the highpressure oil in the accumulator is allowed to flow to the hydraulic motor. The two processes are differentiated by the $3 / 2$ NC solenoid valve open or closed states (Figure 3). During charging process, the $3 / 2$ valve is closed, and the hydraulic fluid is forced to flow into the accumulator, building up pressure in the accumulator. During discharging process, the $3 / 2 \mathrm{NC}$ valve is opened, allowing the high-pressure hydraulic fluid to flow to the hydraulic motor.

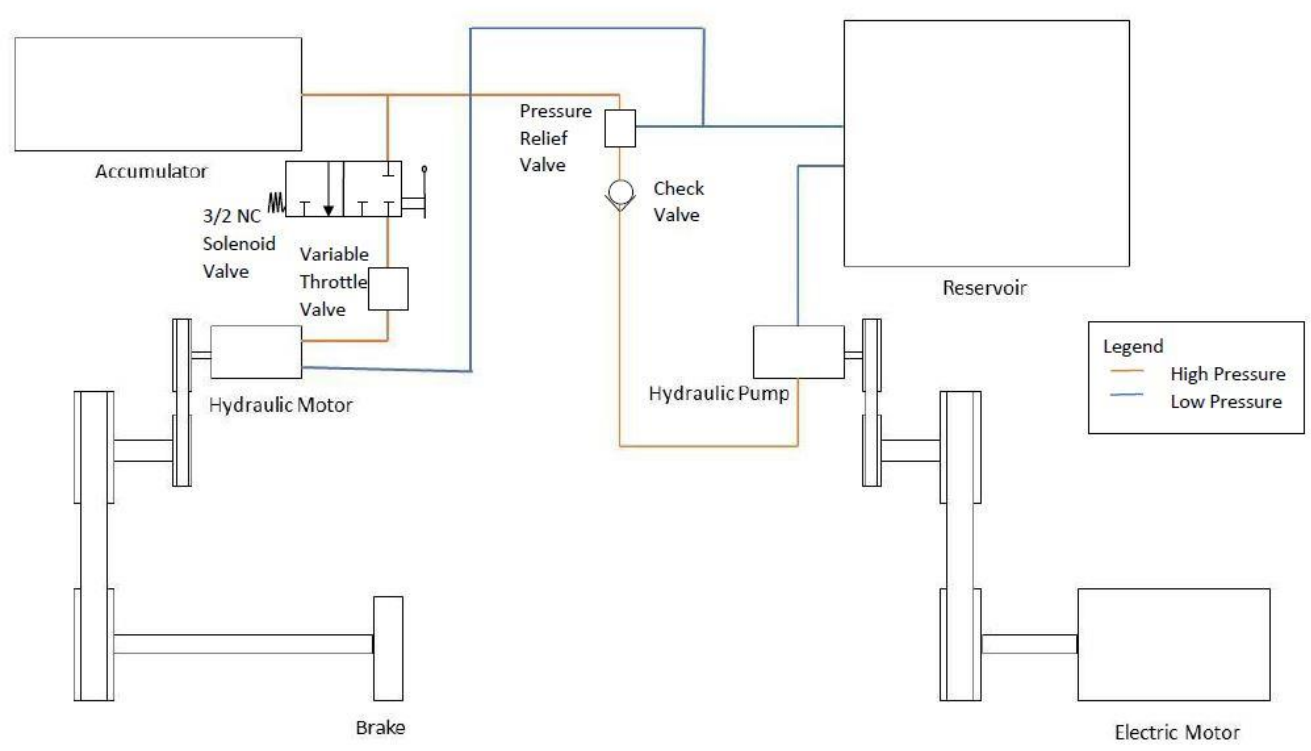

Fig. 3. Schematic diagram of the experimental setup 


\subsection{Determining the Efficiencies}

This study investigates the performance of the regenerative braking system via pump and motor efficiencies. The pump performance is measured via overall efficiency or the multiplication of mechanical and volumetric efficiencies (Eq. (1)). This is because during braking, the wheel is not static and the effect of volumetric loss must be included via volumetric efficiency.

$\eta_{o v r_{p}}=\eta_{m e c h_{p}} \times \eta_{\text {vol }_{p}}$

where,

$\eta_{\text {ovr }}$ = Pump overall efficiency

$\eta_{\text {mech }}=$ Pump mechanical efficiency

$\eta_{\text {vol }_{p}}=$ Pump volumetric efficiency

The hydraulic pump side of the rear axle is connected to an electric motor via a belt drive (Figure 4a). The reaction load of the electric motor from the load cells (Figure $4 b$ ) and the electric motor angular speed are used to obtain the electric motor reaction torque and wheel speed. The load cells used in the experiment is HT Sensor Technology model type TAL 201, which has the accuracy of $\pm 0.02 \%$. The electric motor reaction torque, the gear ratio of the drive train and the mechanical efficiency are used to determine the pump experimental torque (Eq. (2)).

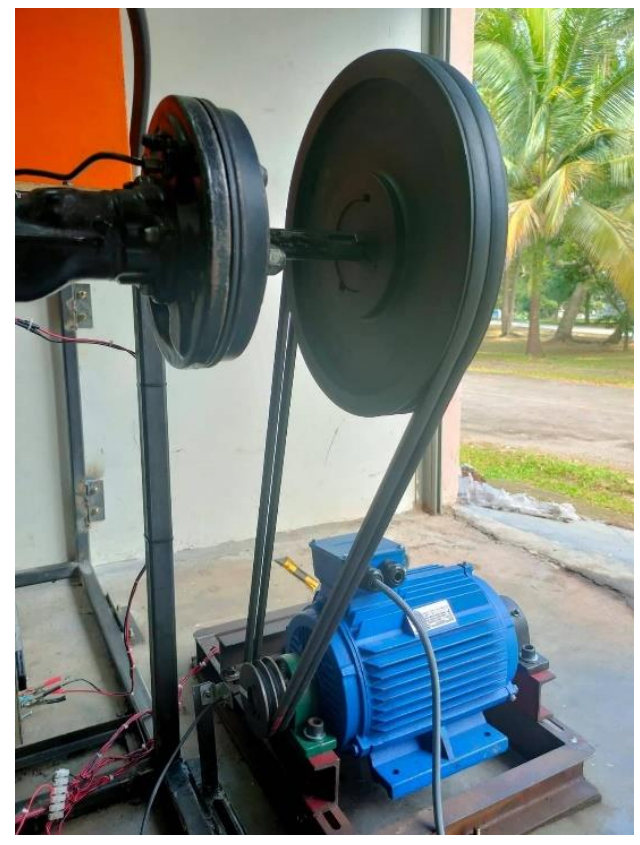

(a)

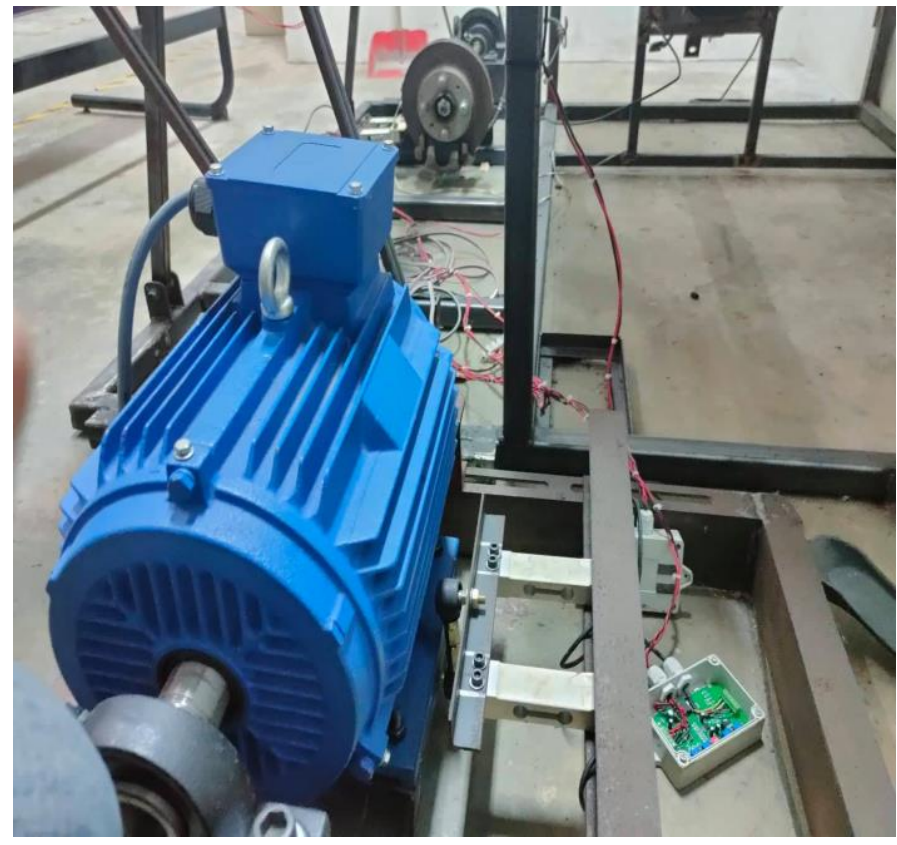

(b)

Fig. 4. (a) The belts setup at the electric motor (b) The load cells setup at the electric motor

$T_{\text {pump }}=\frac{T_{e m} \times B P R_{p}}{G R_{p} \times 0.8}$

where,

$T_{\text {pump }}=$ Experimental pump torque

$T_{e m} \quad=$ Electric motor reaction torque

$B P R_{p}=$ Belt pulley ratio (2.033) 
$G R_{p} \quad=$ Gear ratio (2.538)

$0.8=$ Mechanical efficiency from electric motor to hydraulic pump (20\% loss)

The electric motor speed is controlled to simulate the braking torque when the vehicle decelerating from the speed of $21 \mathrm{~km} / \mathrm{h}, 40 \mathrm{~km} / \mathrm{h}, 60 \mathrm{~km} / \mathrm{h}$, and $80 \mathrm{~km} / \mathrm{h}$. The pressure relief valve is also set to a desired pressure ranging from 25 to 75 -bar while the reaction torque at the electric motor is measured and recorded. The mechanical efficiency of the pump can be obtained from Eq. (3).

$\eta_{\text {mech }}=\frac{T_{\text {pump }}}{T_{\text {pump }}} \times 100 \%$

where,

$T_{\text {pump }_{t}}=$ Theoretical pump torque $\left(T_{\text {pump }}=\frac{P \times D_{p}}{2 \pi}\right)$

$D_{p} \quad=$ Pump displacement

$P \quad=$ Fluid pressure

The volumetric efficiency of the hydraulic pump is determined from a high-pressure external gear pump model [11] (Eq. (4)).

$\eta_{\text {vol }_{p}}=1-\frac{8 \times 10^{-8} \times P}{\mu \times \omega_{p}}$

where,

$\mu \quad=$ Fluid dynamic viscosity (0.029 mPas)

$\omega_{p} \quad=$ Pump speed in rad $/ \mathrm{s}$

The hydraulic motor performance is measured solely via mechanical efficiency since the TTR hybrid is designed to launch from static and the hydraulic motor would be mechanically decoupled as the speed of the hydraulic motor can no longer keep up with the speed of the wheel. The hydraulic motor side of the rear axle is used to obtain its mechanical efficiency where it is connected to a mechanical braking system via a belt drive (Figure 5a). The brake caliper is equipped with load cells (Figure $5 b$ ) so that the static torque of the hydraulic motor can be determined.

During the discharging process, the accumulator is charged to 20-bar of pressure. Then, the mechanical brake locks the lower shaft and the brake caliper so that the torque from the hydraulic motor is transferred to the load cells at the caliper. Next, the solenoid valve releases the highpressure fluid to the hydraulic motor. The load reading from the brake caliper is used to determine the brake torque $\left(T_{b r}\right)$. The experiment is then repeated with different charging pressure. 


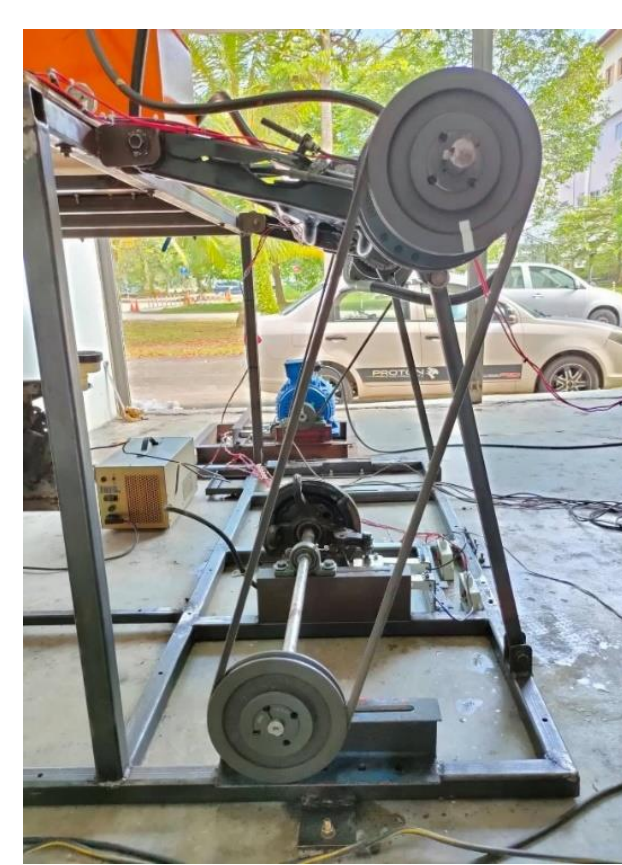

(a)

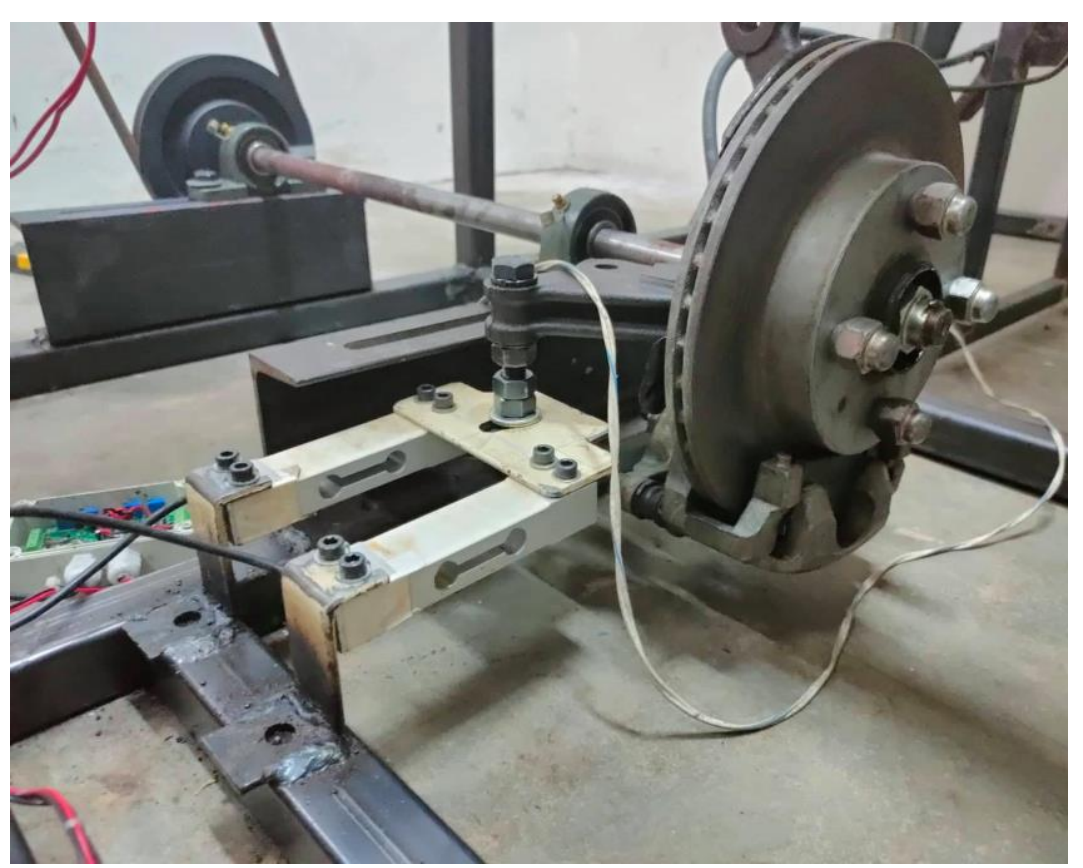

(b)

Fig. 5. (a) The belt pulley setup at the brake caliper (b) The load cells setup at the brake caliper

The experimented motor torque $\left(T_{\text {motor }}\right)$ is obtained from the brake torque multiplied by the gear ratios and the $80 \%$ mechanical efficiency of the drive train (Eq. (5)). Finally, the hydraulic motor mechanical efficiency is obtained (Eq. (6))

$T_{\text {motor }_{e x}}=\frac{T_{b r} \times B P R_{m}}{G R_{m} \times 0.8}$

where,

$T_{\text {motor }_{e x}}=$ Experimented motor torque

$T_{b r} \quad=$ Brake torque

$B P R_{m}=$ Belt pulley ratio (1.005)

$G R_{m}=$ Gear ratio (1.86)

$\eta_{\text {mech }_{m}}=\frac{T_{\text {motor }}}{T_{\text {motor }}} \times 100 \%$

where,

$\eta_{\text {mech }_{m}}=$ Motor mechanical efficiency

$T_{\text {motor }_{e x}}=$ Experimental motor torque

$T_{\text {motor }_{t}}=$ Theoretical motor torques $\left(T_{\text {motor }_{t}}=\frac{P \times D_{m}}{2 \pi}\right)$

$D_{m} \quad=$ Motor displacement $(50 \mathrm{cc} / \mathrm{rev})$

\section{Results and Discussion}

\subsection{Hydraulic Pump Efficiency}

The electric motor is used to simulate the vehicle speeds of $21,40,60$, and $80 \mathrm{~km} / \mathrm{h}$. While the electric motor drives the pump side of the wheel at the mentioned speeds, the charging pressure of the accumulator is varied from 20 to 75 bar with increments of 5 bar. The reaction torque of the 
electric motor is used to determine the pump overall efficiency (Table 1 to Table 4). The best overall efficiencies at each vehicle speed for the hydraulic pump are $69.85 \%$ at $21 \mathrm{~km} / \mathrm{h}$ speed and 35 bar pressure, $76.94 \%$ at $40 \mathrm{~km} / \mathrm{h}$ speed and 70 bar pressure, $82.06 \%$ at $60 \mathrm{~km} / \mathrm{h}$ speed and 75 bar pressure, and $82.91 \%$ at $80 \mathrm{~km} / \mathrm{h}$ speed and 75 bar pressure.

From the results, generally, the pump overall efficiency shows an increasing trend while the pressure increases. Thus, it can be said that under safe conditions, higher pressure is preferable for the hydraulic pump and should be used during the operation of the HHV.The results also shows that the pump operates most efficiently when the vehicle speed is at $80 \mathrm{~km} / \mathrm{h}$ and at the pressure of 75 bar with the overall efficiency of $83 \%$. However, the pump efficiency is more consistent when the vehicle speed is at $60 \mathrm{~km} / \mathrm{h}$ (Figure 6).

Table 1

Test results at $21 \mathrm{~km} / \mathrm{h}$ speed

\begin{tabular}{|c|c|c|c|c|c|c|c|c|c|}
\hline \multirow[t]{2}{*}{ Pressure (bar) } & \multirow[t]{2}{*}{$T_{\text {pump }_{t}}(\mathrm{Nm})$} & \multicolumn{4}{|c|}{$T_{e m}(\mathrm{Nm})$} & \multirow[t]{2}{*}{$T_{\text {pump }_{\text {ex }}}(\mathrm{Nm})$} & \multirow{2}{*}{$\begin{array}{l}\eta_{v_{\text {ool }}} \\
(\%)\end{array}$} & \multirow{2}{*}{$\begin{array}{l}\eta_{\text {mech }_{p}} \\
(\%)\end{array}$} & \multirow{2}{*}{$\begin{array}{l}\eta_{\text {ovr }} \\
(\%)\end{array}$} \\
\hline & & 1 & 2 & 3 & Average & & & & \\
\hline 20 & 7.96 & 10.16 & 11.75 & 11.52 & 11.14 & 11.16 & 89.27 & 71.33 & 63.68 \\
\hline 25 & 9.95 & 11.89 & 13.48 & 13.21 & 12.86 & 12.88 & 86.59 & 77.26 & 66.90 \\
\hline 30 & 11.94 & 13.47 & 15.08 & 14.93 & 14.49 & 14.51 & 83.91 & 82.25 & 69.01 \\
\hline 35 & 13.93 & 14.99 & 16.82 & 16.71 & 16.17 & 16.19 & 81.22 & 86.00 & 69.85 \\
\hline 40 & 15.92 & 17.85 & 19.05 & 18.34 & 18.41 & 18.43 & 78.54 & 86.34 & 67.81 \\
\hline 45 & 17.90 & 19.34 & 20.32 & 20.11 & 19.92 & 19.95 & 75.86 & 89.77 & 68.10 \\
\hline 50 & 19.89 & 20.66 & 21.92 & 21.92 & 21.50 & 21.53 & 73.18 & 92.41 & 67.63 \\
\hline 55 & 21.88 & 22.10 & 23.90 & 23.63 & 23.21 & 23.24 & 70.49 & 94.17 & 66.39 \\
\hline 60 & 23.87 & 23.33 & 25.75 & 25.19 & 24.76 & 24.79 & 67.81 & 96.31 & 65.31 \\
\hline 65 & 25.86 & 25.43 & 27.03 & 27.05 & 26.50 & 26.53 & 65.13 & 97.47 & 63.48 \\
\hline 70 & 27.85 & 26.94 & 28.45 & 28.53 & 27.97 & 28.01 & 62.45 & 99.44 & 62.09 \\
\hline 75 & 29.84 & 29.71 & 30.52 & 30.34 & 30.19 & 30.23 & 59.76 & 98.72 & 59.00 \\
\hline
\end{tabular}

Table 2

Test results at $40 \mathrm{~km} / \mathrm{h}$ speed

\begin{tabular}{|c|c|c|c|c|c|c|c|c|c|}
\hline \multirow[t]{2}{*}{ Pressure (bar) } & \multirow[t]{2}{*}{$T_{\text {pumpt }}(\mathrm{Nm})$} & \multicolumn{4}{|c|}{$T_{e m}(\mathrm{Nm})$} & \multirow[t]{2}{*}{$T_{\text {pump }_{\text {ex }}}(\mathrm{Nm})$} & \multirow{2}{*}{$\begin{array}{l}\eta_{\text {vol }_{p}} \\
(\%)\end{array}$} & \multirow{2}{*}{$\begin{array}{l}\eta_{\text {mech }_{p}} \\
(\%)\end{array}$} & \multirow{2}{*}{$\begin{array}{l}\eta_{o v r_{p}} \\
(\%)\end{array}$} \\
\hline & & 1 & 2 & 3 & Average & & & & \\
\hline 20 & 7.96 & 11.94 & 12.49 & 12.09 & 12.17 & 12.19 & 94.37 & 65.30 & 61.62 \\
\hline 25 & 9.95 & 13.90 & 14.21 & 13.70 & 13.94 & 13.96 & 92.96 & 71.26 & 66.24 \\
\hline 30 & 11.94 & 15.51 & 15.78 & 15.39 & 15.56 & 15.58 & 91.55 & 76.63 & 70.16 \\
\hline 35 & 13.93 & 17.48 & 17.71 & 17.27 & 17.49 & 17.51 & 90.14 & 79.53 & 71.69 \\
\hline 40 & 15.92 & 19.10 & 19.25 & 18.97 & 19.11 & 19.13 & 88.73 & 83.20 & 73.82 \\
\hline 45 & 17.90 & 20.73 & 21.00 & 20.66 & 20.80 & 20.82 & 87.33 & 85.98 & 75.08 \\
\hline 50 & 19.89 & 22.50 & 22.54 & 22.23 & 22.42 & 22.45 & 85.92 & 88.61 & 76.13 \\
\hline 55 & 21.88 & 24.20 & 24.48 & 23.90 & 24.19 & 24.23 & 84.51 & 90.34 & 76.34 \\
\hline 60 & 23.87 & 25.80 & 26.16 & 25.44 & 25.80 & 25.83 & 83.10 & 92.41 & 76.79 \\
\hline 65 & 25.86 & 27.49 & 29.31 & 29.31 & 28.71 & 28.74 & 81.69 & 89.98 & 73.51 \\
\hline 70 & 27.85 & 29.00 & 29.31 & 28.76 & 29.03 & 29.06 & 80.28 & 95.84 & 76.94 \\
\hline 75 & 29.84 & 30.48 & 31.16 & 30.42 & 30.69 & 30.73 & 78.88 & 97.12 & 76.60 \\
\hline
\end{tabular}


Table 3

Test results at $60 \mathrm{~km} / \mathrm{h}$ speed

\begin{tabular}{|c|c|c|c|c|c|c|c|c|c|}
\hline \multirow[t]{2}{*}{ Pressure (bar) } & \multirow[t]{2}{*}{$T_{\text {pump }_{t}}(\mathrm{Nm})$} & \multicolumn{4}{|c|}{$T_{e m}(\mathrm{Nm})$} & \multirow[t]{2}{*}{$T_{\text {pump }_{\text {ex }}}(\mathrm{Nm})$} & \multirow{2}{*}{$\begin{array}{l}\eta_{v_{o l} l_{p}} \\
(\%)\end{array}$} & \multirow{2}{*}{$\begin{array}{l}\eta_{\text {mech }_{p}} \\
(\%)\end{array}$} & \multirow{2}{*}{$\begin{array}{l}\eta_{o v r_{p}} \\
\text { (\%) }\end{array}$} \\
\hline & & 1 & 2 & 3 & Average & & & & \\
\hline 20 & 7.96 & 12.81 & 12.60 & 12.78 & 12.73 & 12.75 & 96.24 & 62.44 & 60.09 \\
\hline 25 & 9.95 & 14.69 & 14.48 & 14.30 & 14.49 & 14.51 & 95.31 & 68.57 & 65.35 \\
\hline 30 & 11.94 & 16.55 & 16.23 & 16.14 & 16.31 & 16.33 & 94.37 & 73.10 & 68.99 \\
\hline 35 & 13.93 & 18.23 & 18.18 & 17.99 & 18.13 & 18.16 & 93.43 & 76.70 & 71.66 \\
\hline 40 & 15.92 & 20.21 & 20.14 & 19.76 & 20.04 & 20.06 & 92.49 & 79.33 & 73.37 \\
\hline 45 & 17.90 & 21.44 & 21.31 & 21.17 & 21.31 & 21.33 & 91.55 & 83.93 & 76.83 \\
\hline 50 & 19.89 & 23.25 & 23.02 & 22.76 & 23.01 & 23.04 & 90.61 & 86.34 & 78.24 \\
\hline 55 & 21.88 & 25.22 & 24.87 & 24.60 & 24.90 & 24.93 & 89.67 & 87.78 & 78.71 \\
\hline 60 & 23.87 & 26.76 & 26.45 & 26.32 & 26.51 & 26.55 & 88.73 & 89.93 & 79.80 \\
\hline 65 & 25.86 & 28.35 & 28.00 & 28.07 & 28.14 & 28.17 & 87.79 & 91.80 & 80.59 \\
\hline 70 & 27.85 & 29.95 & 29.78 & 29.12 & 29.61 & 29.65 & 86.86 & 93.93 & 81.58 \\
\hline 75 & 29.84 & 31.25 & 31.27 & 31.09 & 31.20 & 31.24 & 85.92 & 95.51 & 82.06 \\
\hline
\end{tabular}

Table 4

Test results at $80 \mathrm{~km} / \mathrm{h}$ speed

\begin{tabular}{|c|c|c|c|c|c|c|c|c|c|}
\hline \multirow[t]{2}{*}{ Pressure (bar) } & \multirow[t]{2}{*}{$T_{\text {pump }_{t}}(\mathrm{Nm})$} & \multicolumn{4}{|c|}{$T_{e m}(\mathrm{Nm})$} & \multirow[t]{2}{*}{$T_{\text {pump }_{\text {ex }}}(\mathrm{Nm})$} & \multirow{2}{*}{$\begin{array}{l}\eta_{v_{\text {ol }}} \\
(\%)\end{array}$} & \multirow{2}{*}{$\begin{array}{l}\eta_{\text {mech }_{p}} \\
(\%)\end{array}$} & \multirow{2}{*}{$\begin{array}{l}\eta_{o v r_{p}} \\
(\%)\end{array}$} \\
\hline & & 1 & 2 & 3 & Average & & & & \\
\hline 20 & 7.96 & 13.38 & 13.55 & 13.38 & 13.46 & 13.48 & 97.18 & 59.03 & 57.37 \\
\hline 25 & 9.95 & 16.06 & 14.97 & 14.92 & 15.51 & 15.53 & 96.48 & 64.04 & 61.79 \\
\hline 30 & 11.94 & 17.53 & 16.91 & 16.68 & 17.22 & 17.24 & 95.78 & 69.23 & 66.30 \\
\hline 35 & 13.93 & 19.28 & 18.84 & 18.89 & 19.06 & 19.08 & 95.07 & 72.97 & 69.38 \\
\hline 40 & 15.92 & 20.05 & 20.54 & 20.50 & 20.30 & 20.32 & 94.37 & 78.32 & 73.91 \\
\hline 45 & 17.90 & 22.85 & 21.85 & 21.89 & 22.35 & 22.37 & 93.66 & 80.02 & 74.95 \\
\hline 50 & 19.89 & 25.40 & 23.49 & 24.13 & 24.44 & 24.47 & 92.96 & 81.29 & 75.56 \\
\hline 55 & 21.88 & 26.24 & 25.28 & 25.64 & 25.76 & 25.79 & 92.25 & 84.84 & 78.27 \\
\hline 60 & 23.87 & 27.68 & 27.04 & 27.25 & 27.36 & 27.39 & 91.55 & 87.16 & 79.79 \\
\hline 65 & 25.86 & 29.57 & 30.10 & 28.94 & 29.84 & 29.87 & 90.85 & 86.57 & 78.65 \\
\hline 70 & 27.85 & 30.67 & 30.24 & 30.44 & 30.45 & 30.49 & 90.14 & 91.35 & 82.34 \\
\hline 75 & 29.84 & 32.33 & 31.97 & 32.15 & 32.15 & 32.19 & 89.44 & 92.70 & 82.91 \\
\hline
\end{tabular}

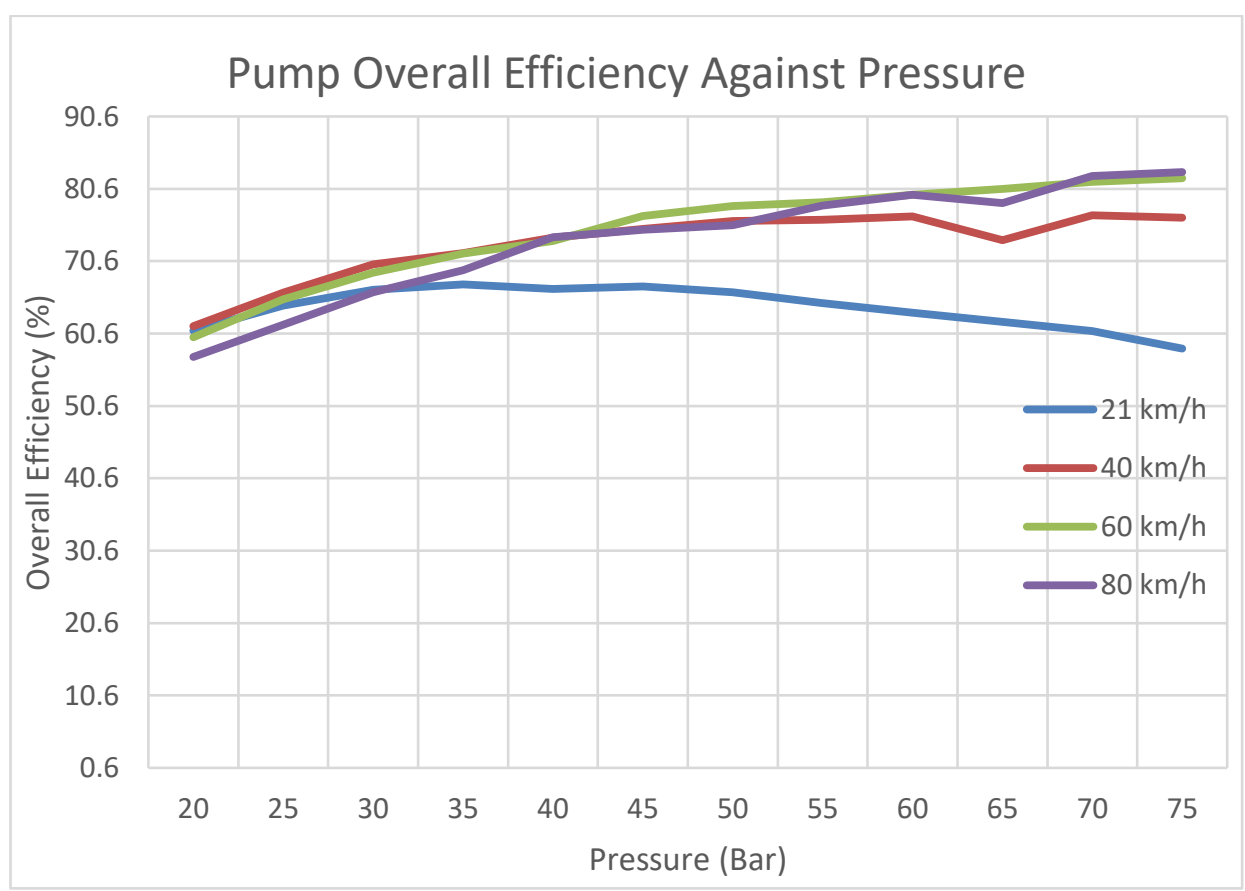

Fig. 6. Overall efficiency of hydraulic pump against pressure 


\subsection{Hydraulic Motor Efficiency}

The hydraulic motor static torque is measured when the motor is supplied with hydraulic fluid at pressure between 20 bar to 75 bar (Figure 7). The torque value from load cell is used to calculate the hydraulic motor mechanical efficiency and is shown in Table 5. The mechanical efficiency of the hydraulic motor ranges from $62 \%$ to $74 \%$.

The hydraulic motor mechanical efficiency records high values at the pressure between 20 bar to 40 bar. However, the mechanical efficiency drops at the pressure from 40 bar to 65 bar and rise again beyond 65 bar. The hydraulic motor operates most efficiently when it operates at 75 bar of discharging pressure. Thus, during the operation of the HHV vehicle, the discharging pressure should be set higher than 65 bar.

Table 5

Hydraulic motor mechanical efficiency

\begin{tabular}{|c|c|c|c|c|c|c|c|c|}
\hline \multirow{2}{*}{$\begin{array}{l}\text { Pressure } \\
\text { (Bar) }\end{array}$} & \multirow{2}{*}{$\begin{array}{l}T_{\text {motor }_{t}} \\
(\mathrm{Nm})\end{array}$} & \multicolumn{5}{|c|}{$T_{b r}$} & \multirow{2}{*}{$\begin{array}{l}T_{\text {motor }} \text { ex } \\
(\mathrm{Nm})\end{array}$} & \multirow{2}{*}{$\begin{array}{l}\eta_{\text {mech }_{m}} \\
(\%)\end{array}$} \\
\hline & & 1 & 2 & 3 & 4 & Average & & \\
\hline 20 & 15.92 & 21.95 & 4.07 & 15.63 & 16.99 & 14.66 & 7.92 & 62.21 \\
\hline 25 & 19.89 & 31.00 & 5.71 & 20.12 & 20.77 & 19.40 & 10.48 & 65.86 \\
\hline 30 & 23.87 & 43.90 & 15.10 & 18.30 & 22.73 & 25.01 & 13.51 & 70.75 \\
\hline 35 & 27.85 & 40.70 & 20.50 & 19.03 & 28.37 & 27.15 & 14.67 & 65.84 \\
\hline 40 & 31.83 & 47.40 & 22.84 & 25.42 & 34.05 & 32.43 & 17.52 & 68.81 \\
\hline 45 & 35.81 & 43.60 & 24.45 & 23.40 & 31.04 & 30.62 & 16.55 & 57.76 \\
\hline 50 & 39.79 & 43.90 & 25.50 & 32.63 & 33.85 & 33.97 & 18.35 & 57.66 \\
\hline 55 & 43.77 & 52.20 & 26.66 & 35.50 & 31.94 & 36.58 & 19.76 & 56.44 \\
\hline 60 & 47.75 & 45.50 & 36.14 & 41.46 & 40.81 & 40.98 & 22.14 & 57.97 \\
\hline 65 & 51.73 & 44.80 & 47.17 & 47.22 & 43.13 & 45.58 & 24.63 & 59.52 \\
\hline 70 & 55.70 & 54.70 & 57.80 & 55.42 & 58.93 & 56.71 & 30.64 & 68.76 \\
\hline 75 & 59.68 & 59.30 & 68.90 & 68.51 & 64.66 & 65.34 & 35.31 & 73.95 \\
\hline
\end{tabular}

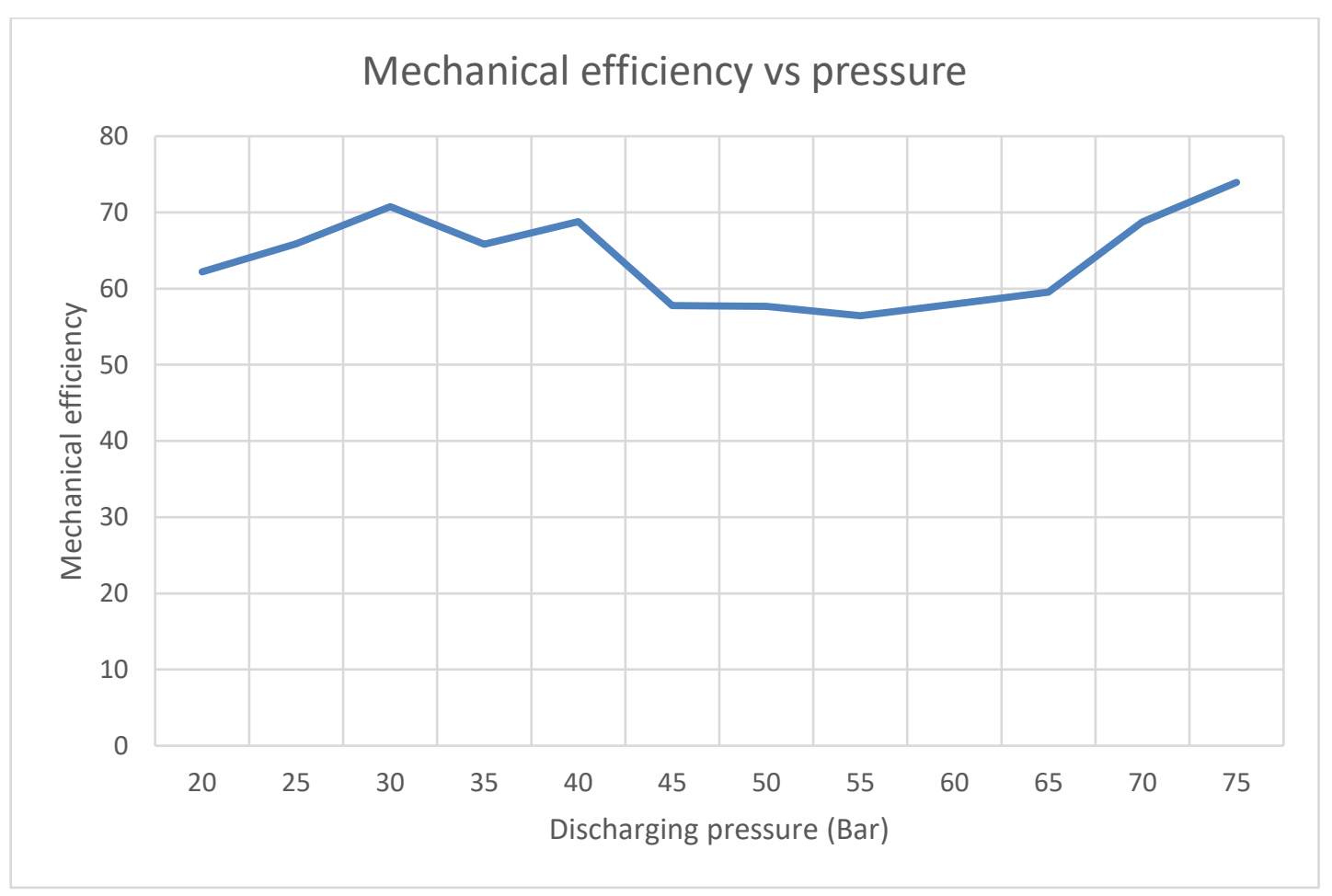

Fig. 7. Motor Mechanical efficiency vs discharging pressure 


\section{Conclusion}

This experiment study explores the performance of the HHV drivetrain for passenger vehicle by determining the highest overall efficiency of the pump and the highest mechanical efficiency of the motor in the TTR regenerative braking system. The pump performs at its highest efficiency of $82 \%$ when the vehicle is braking from $60 \mathrm{~km} / \mathrm{h}$ and charging to 75 bar. The motor performs at its highest mechanical efficiency of $74 \%$ discharging the accumulator from the pressure of 75 bar. This study suggests the TTR HHV should be operated at the pressure higher than 65 bar because that is the optimal operating pressure of the drive train.

\section{Acknowledgement}

This research was funded by RUI khas 1001/PMEKANIK/8014032 grant.

\section{Reference}

[1] IEA. "Fuel Consumption of Cars and Vans." 2020.

[2] Conti, John, Paul Holtberg, Jim Diefenderfer, Angelina LaRose, James T. Turnure, and Lynn Westfall. International energy outlook 2016 with projections to 2040. No. DOE/EIA-0484 (2016). USDOE Energy Information Administration (EIA), Washington, DC (United States). Office of Energy Analysis, 2016. https://doi.org/10.2172/1296780

[3] Fontaras, Georgios, Panayotis Pistikopoulos, and Zissis Samaras. "Experimental evaluation of hybrid vehicle fuel economy and pollutant emissions over real-world simulation driving cycles." Atmospheric environment 42, no. 18 (2008): 4023-4035. https://doi.org/10.1016/j.atmosenv.2008.01.053

[4] Ibrahim, Nurru Anida, Idrus Salimi Ismail, Siti Norbakyah Jabar, and Salisa Abdul Rahman. "A Study on the Effects of Plug-In Hybrid Electric Vehicle (PHEV) Powertrain on Fuel Consumption, Electric Consumption and Emission using Autonomie." Journal of Advanced Research in Applied Sciences and Engineering Technology 16, no. 1 (2019): 4956.

[5] Deng, Da. "Li-ion batteries: basics, progress, and challenges." Energy Science \& Engineering 3, no. 5 (2015): $385-$ 418. https://doi.org/10.1002/ese3.95

[6] Propfe, Bernd, Martin Redelbach, Danilo J. Santini, and Horst Friedrich. "Cost analysis of plug-in hybrid electric vehicles including maintenance \& repair costs and resale values." World Electric Vehicle Journal 5, no. 4 (2012): 886-895. https://doi.org/10.3390/wevj5040886

[7] Ramdan, Muhammad Iftishah, and Kim A. Stelson. "Optimal design of a power-split hybrid hydraulic bus." Proceedings of the Institution of Mechanical Engineers, Part D: Journal of Automobile Engineering 230, no. 12 (2016): 1699-1718. https://doi.org/10.1177/0954407015621817

[8] Yusof, Ahmad Anas, Saiful Akmal Sabaruddin, Syarizal Bakri, and Suhaimi Misha. "Simulation of System Pressure Impact on the Water Hydraulic Hybrid Driveline Performance." CFD Letters 10, no. 2 (2018): 59-75.

[9] Ramdan, Muhammad I., and Kim A. Stelson. "Optimized single-stage power-split hydraulic hybrid city bus." In Fluid Power Systems Technology, vol. 56086, p. V001T01A012. American Society of Mechanical Engineers, 2013. https://doi.org/10.1115/FPMC2013-4420

[10] Ramdan, Muhammad Iftishah, Khairul Anuar Idris, Yeoh Ying Heng, Muhammad Syahir Mahyuddin, Mohd Azmi Ismail, and Ahmad Faizul Hawary. "Optimization of The Through-The-Road Parallel Hydraulic Hybrid Drive Train." Journal of Advanced Research in Fluid Mechanics and Thermal Sciences 75, no. 1 (2020): $104-111$. https://doi.org/10.37934/arfmts.75.1.104111

[11] Hydraulics \& Pneumatics. "Engineering Essentials: Fundamentals of Hydraulic Pumps." 2012.

[12] Hydraulic, BP. "Gear Pump (HGP Series)." n.d.

[13] Vanklaveren, Whitney. "Types of hydraulic pumps." 2018.

[14] Bergman, Simon, and Vendelah Tenenbaum Svengren. "En energibesparande oljepump-Produktframtagning." (2017).

[15] Factory, Fei Yue Hydraulic. "Hydraulic Motor BMR/OMR series." n.d. 6. 